\title{
A polymorphic centric fusion enhances chiasma interference in Leptysma argentina (Orthoptera): a chiasma distribution study
}

\author{
PABLO C. COLOMBO* \\ Laboratorio de Genética, Departamento de Ciencias Biológicas, Facultad de Ciencias Exactas y Naturales, Universidad \\ de Buenos Aires, Intendente Güiraldes y Costanera Norte, (1428) Buenos Aires, Argentina
}

\begin{abstract}
A chiasma distribution study in diplotene in the grasshopper Leptysma argentina revealed that: (i) chiasma interference plays a central role in determining chiasma distribution in bivalents carrying two or more chiasmata in this species; (ii) the distance of interference $(i)$ increases significantly in fusion carriers, and this effect is additive (is more pronounced in fusion homozygotes than in heterozygotes). This increase is due to a genuine intensification of chiasma interference; (iii) chiasma interference is operative across the centromere; and (iv) across-centromere interference is also influenced by the karyotype, in the same fashion as non trans-centromeric interference. Finally, a discussion concerning the possible origin of the fusion $3 / 6$ polymorphism is held.
\end{abstract}

Keywords: centric fusions, chiasma distribution, chiasma interference, Orthoptera, Robertsonian rearrangements.

\section{Introduction}

\section{Theoretical framework}

Chiasma distribution studies were started by Mather (1936, 1937), who - after a series of investigations of the relation between chromosome length and chiasma frequency in several species, as well as crossover event distribution in Drosophila - suggested that chiasma formation is sequential from a fixed point, purportedly the centromere. The distance between the starting point and first chiasma he called the 'differential distance' $d$; the distance between the first and the second chiasmata, and between all subsequent chiasmata was named the 'interference distance' $i$; the 'residual distance' $r$ being the remaining bivalent length. However, Mather did not advance any mechanism of chiasma formation and consequently, $d, i$ and $r$ distances should be considered as purely descriptive concepts (Jones, 1987).

Henderson (1963), who mapped chiasma distribution in the grasshopper Schistocerca gregaria to test Mather's hypothesis, concluded that chiasma forma-

* Member of the Consejo Nacional de Investigaciones Científicas y Técnicas (National Council of Scientific and Technical Research Argentina). tion in that species begins at both ends (centromeric and telomeric) simultaneously. Fox (1973) re-examined Schistocerca and proposed that chiasma formation is sequential from the telomere onwards, and that subsequent chiasma formation would be conditioned only by interference. Other studies in grasshoppers (Shaw \& Knowles, 1976; Coates \& Shaw, 1982), in mouse oocytes (Maudlin \& Evans, 1980) and in human spermatocytes (Hultén, 1974) also interpreted their results in terms of Mather's sequential model; all of them ascribed to interference a central role in chiasma position regulation (Jones, 1987) and (with the exception of Coates \& Shaw, 1982), proposed telomeres rather than centromeres as the starting point of the sequence.

\section{The problem}

Leptysma argentina Bruner (Acrididae: Orthoptera) displays a chromosome number $2 n=210^{*} / 22 \%$ and a sex determination mechanism of $\mathrm{XO} / \mathrm{XX}$. Its chromosome complement consists of one large metacentric (pair 1), one large telocentric (pair 2), six medium-sized telocentric (pairs 3-8) and two small telocentric chromosomes (9-10). The $\mathrm{X}$-chromosome is also telocentric and its size is comparable to that of the 


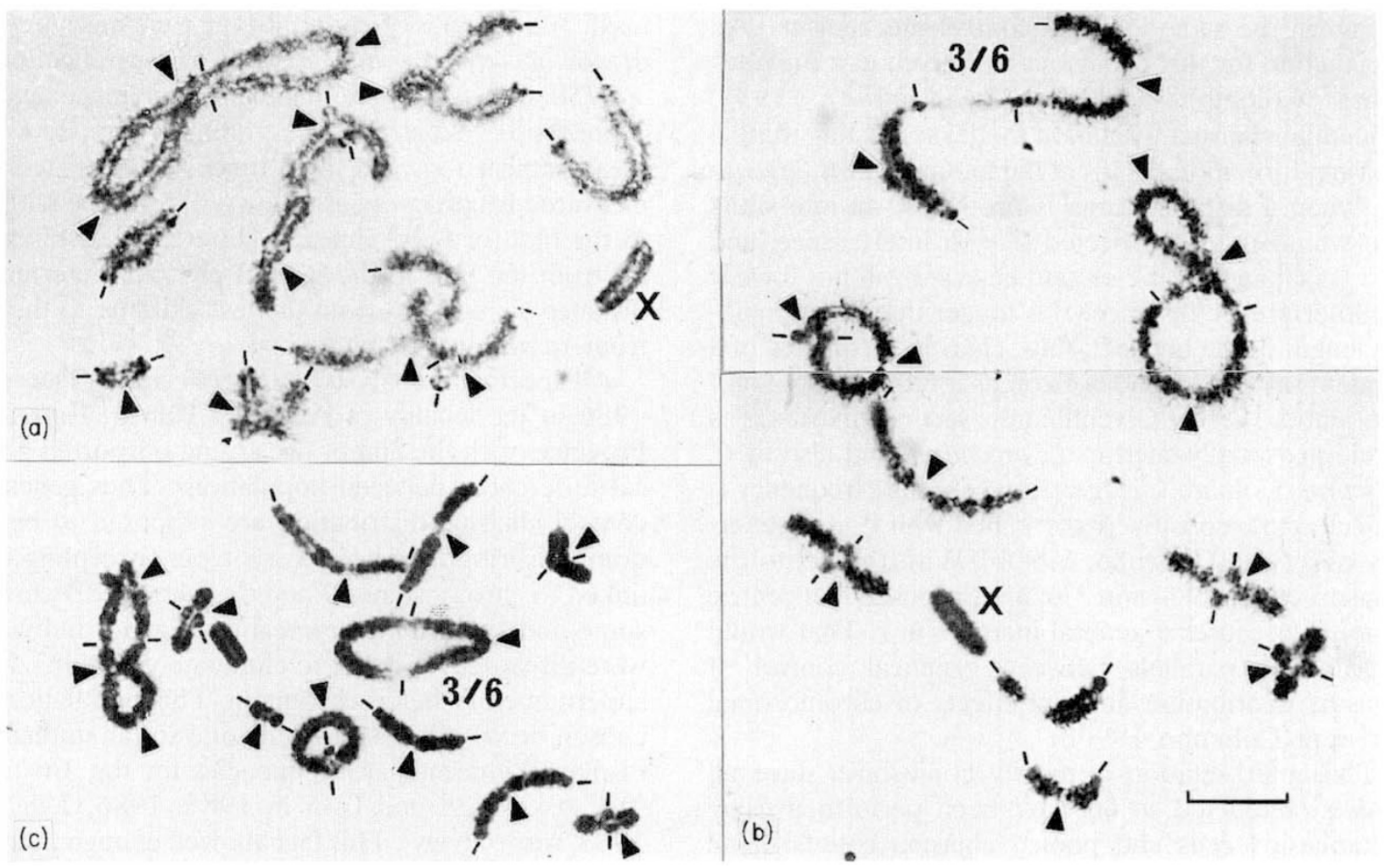

Fig. 1 Leptysma argentina. Diplotene cells of a basic homozygote $(A)$, a heterozygote $(B)$ and a homozygote for fusion $3 / 6(C)$ as used in the present work. Centromeres are indicated by small bars and chiasmata are marked by arrowheads. The trivalent of heterozygotes and the newly arisen metacentric bivalent of fusion homozygotes are indicated as ' $3 / 6$ '. Bar $=10 \mu \mathrm{m}$.

medium-sized chromosomes (Bidau \& Hasson, 1984) (Fig. 1).

In previous papers the occurrence of four chromosome polymorphisms (affecting both chiasma distribution and body size) was described in nine Argentine populations of $L$. argentina, namely: (i) a centric fusion between telocentric chromosomes 3 and 6 that can produce three karyotypes: basic homozygote (BB), heterozygote (BF) or fusion homozygote (FF); (ii) and (iii) two supernumerary segments in pair 10 ; and (iv) a B-chromosome. Fusion 3/6 was found to be correlated with a significant and additive increase in carrier body size (Colombo, 1989a, b; 1990a). Moreover, this rearrangement is associated with intra- and interchromosomal effects on chiasma frequency and position (Colombo 1987, 1989b, 1990b) with a consequent dramatic decrease in total recombination, such as (i) the origin of a new linkage group (ii) virtual suppression of proximal (P) and interstitial (I) chiasmata in the 3/6 metacentric (which causes a strict distal localization of chiasmata). These intrachromosomal effects are adaptive, since unrestricted chiasma formation in the trivalent state of heterozygotes would produce high frequencies of non-convergent orientation and hence unbalanced gametes (Hewitt, 1979;
Colombo, 1987, 1989a; Bidau \& Mirol, 1988) and (iii) decrease of total ( $T$ ) chiasma frequency, mainly explained by a diminution of $\mathrm{P}$ and to a lesser extent $\mathrm{I}$ chiasmata frequency plus a slight increase of the distal (D) chiasma frequency in chromosomes other than $3+6$. These interchromosomal effects are stronger in fusion homozygotes than in heterozygotes and are therefore roughly additive.

When correlation analyses for all possible combinations of chiasma variables (P, I, D and T) were carried out within karyotypes, the only highly significant correlations obtained were for $\mathrm{P}$ vs. T (positive) and I vs. D (negative) (Colombo, 1990b). These facts are relevant, since they reveal that modifications in $\mathrm{T}$ are due to an increase or decrease of $\mathrm{P}$ ( $\mathrm{I}+\mathrm{D}$ does not correlate with $\mathrm{T}$ ). These results are consistent with between-karyotype analyses and also with interpopulation studies (where populations with different frequencies of $3 / 6$ were compared, regardless of karyotype), since in both cases changes in $\mathrm{T}$ are explained by changes in $\mathrm{P}$ (Colombo, 1990b). It was therefore concluded that intrakaryotype interindividual variation mainly of genetic and/or environmental origin - is similar to that induced by the rearrangement; hence, both genetic and chromosomal factors appear to be 
acting on the same chiasma control mechanisms. An explanation for this behaviour was given in a previous paper (Colombo, 1990b) using Mather's (1937) sequential chiasma formation model suggesting that: $(i)$ chiasma formation begins at the telomere in $L$. argenti$n a$; when a distal chiasma is produced, an interstitial one would not be expected due to interference, and vice versa; and (ii) the second chiasma will not form if the interference distance $(i)$ is longer than the remaining length of the bivalent; thus, chiasma frequency of a bivalent should depend both on its total length and on $i$ (Colombo, 1990b). Given that the second chiasma is as a rule proximally sited in $L$. argentina (and also in $C$. obscurus; Colombo, 1989c), total chiasma frequency is expected to be positively correlated with $\mathrm{P}$, as is generally observed (Colombo, 1990b). With respect to the chiasma effects of fusion $3 / 6$, it is proposed that centric fusion $3 / 6$ causes a general increase in $i$. That would explain the parallels between genetical control of chiasma distribution and the effects of chromosomal variation (Colombo, 1990b).

This interpretation is merely conjecture, since all studies conducted so far have been performed using metaphase I cells and pooled chiasma counts of all bivalents (except chromosomes 3 and 6, and 3/6). In the present paper a study in diplotene cells is developed, and the following experimental design applied to L. argentina.

\section{Material and methods}

The experimental design used here is basically the same as that employed by Fox (1973) in Schistocerca gregaria noting the presence of metacentrics in $L$. argentina. Assuming that chiasma formation proceeds from the telomere to the centromere, chiasma distribution along the bivalents was mapped, so obtaining distances, $d, i$ and $r$; total, proximal, interstitial and distal chiasma frequencies were also registered according to the criterion employed previously. Since $L$. argentina has metacentric chromosomes, each arm was considered separately. In this study diplotene cells were used to allow an accurate determination of chiasma position (Fig. 1). Cells were selected, taking care that:

(i) each cell was complete and identifiable from any others in its vicinity;

(ii) centromere position could be unambiguously detected;

(iii) there was no ambiguity between chiasmata and relational coiling of homologues.

With this intention eight standard homozygotes, 10 heterozygotes and nine fusion $3 / 6$ homozygotes were used; 10 examples of each cell-type were measured and drawn in camera lucida with a magnification of $\times 3750$. Measures were made using an image analyser (Mini-mop, Kontron Eletronik Gruppe), each measurement repeated three times and averaged. The measured lengths were as follows: (i) from the telomere to the first (or only) chiasma (differential distance, $d$ ); (ii) from the first to the second chiasma (interference distance, $i$ ); and (iii) from the last chiasma to the centromere (residual distance, $r$ ).

All specimens analysed were collected in December 1986 in the locality of Arroy El Palmar, Entre Ríos Province, with the aim of discarding purported genetical differences between populations. Thus genes that control chiasma distribution are supposed to be randomly distributed among karyotypes (excepting those linked to chromosomes 3 and 6). Likewise, B-chromosome and supernumerary segment carrier individuals were discarded, in order to eliminate variations due to supernumerary heterochromatin. This population was chosen because it was the only one so far studied that displayed intermediate frequencies for the $3 / 6$ fusion $(0.5,0.42,0.38$ and 0.45 in $1985,1986,1987$ and 1988 , respectively). This fact allowed enough individuals of each karyotype to be collected with a minimum of capture effort.

All individuals were dissected in the field, their testes fixed in 3:1 ethanol: acetic acid, and stored at $4^{\circ} \mathrm{C}$. Cytological preparations were obtained by squashing in lactoproprionic orcein.

Numerical data obtained from the measurements were scored and processed in a personal computer, using a BASIC program specifically designed by the author; these data were transformed into percentage of total autosomal length per cell, and chromosomes automatically ordered according to their length.

\section{Results and discussion}

\section{Interference distance}

Differences between karyotypes. With the aim of determining whether fusion $3 / 6$ has interchromosome effects on $i$, statistical tests were developed to compare mean $i$ values for each chromosome (or chromosome arm) in all three karyotypes. The arms of metacentrics were treated separately, the long arm of pair 1 will be referred to as ' $1 \mathrm{~L}$ ', and the short arm as ' $1 \mathrm{~S}$ '. Likewise, both arms of metacentric $3 / 6$ in fusion carriers will be called ' $3 /-$ ' and ' $-/ 6$ ', stressing the fact that they are now part of a metacentric chromosome. Given that frequencies $\mathrm{T}, \mathrm{P}, \mathrm{I}$ and $\mathrm{D}$ display highly significant variation among individuals (Colombo, 1990b), individual 
variation was assessed by means of an ANOVA (nested design) in our analysis of distance $i$ between karyotypes. Differences between individuals were in all cases not significant and consequently data from different individuals were pooled. Among all 9 chromosomes that may form two chiasmata (normally pairs 9 and 10 form only one), 6 showed a dosage effect of centric fusion $3 / 6$ in increasing distance $i$. These chromosomes were: telocentrics 2, 4 and 5 (differences significant at the $0.1,1$ and 5 per cent level, respectively) and chromosome 7 , where analyses produced borderline significance $(P=0.0933)$; for metacentrics, the arms $1 \mathrm{~L}$

Table 1 Total $(t)$ and interference $\left(i_{1}\right)$ distances per chromosome or chromosome arm, expressed as a percentage of total autosomal length (see Materials and Methods). In this table the average values of 10 cells from 8,10 and 9 standard homozygotes, heterozygotes and fusion homozygotes, respectively, for $3 / 6$ fusion of Leptysma argentina are given. An analysis of variance comparing average interference distances for each karyomorph was carried out; variance ratios, degrees of freedom (between parentheses) and significance level (with asterisks) are shown. Given that interference distance $i$ is the distance between the first and the second chiasmata, in this table only cells with two chiasmata were considered. $\mathrm{BB}=$ standard homozygotes; $\mathrm{BF}=$ heterozygotes; $\mathrm{FF}=$ fusion homozygotes

\begin{tabular}{|c|c|c|c|c|c|}
\hline & & \multicolumn{3}{|c|}{ Karyotypes } & \\
\hline & & $\mathrm{BB}$ & $\mathrm{BF}$ & $\mathrm{FF}$ & \\
\hline $1 \mathrm{~L}$ & $\begin{array}{l}t \\
i_{1}\end{array}$ & $\begin{array}{r}15.56 \\
9.99\end{array}$ & $\begin{array}{l}16.19 \\
10.28\end{array}$ & $\begin{array}{l}15.50 \\
11.62\end{array}$ & $\begin{array}{l}4.66^{*} \\
(2 ; 146)\end{array}$ \\
\hline 2 & $\begin{array}{l}t \\
i_{1}\end{array}$ & $\begin{array}{r}13.97 \\
9.63\end{array}$ & $\begin{array}{l}14.11 \\
10.97\end{array}$ & $\begin{array}{l}13.93 \\
11.70\end{array}$ & $\begin{array}{l}20.54^{* * *} \\
(2 ; 210)\end{array}$ \\
\hline $1 \mathrm{~S}$ & $\begin{array}{l}t \\
i_{1}\end{array}$ & $\begin{array}{r}11.43 \\
7.52\end{array}$ & $\begin{array}{r}12.35 \\
8.21\end{array}$ & $\begin{array}{r}10.98 \\
7.21\end{array}$ & $\begin{array}{l}1.43 \mathrm{~ns} \\
(2 ; 74)\end{array}$ \\
\hline $3 /-$ & $\begin{array}{l}t \\
i_{1}\end{array}$ & $\begin{array}{r}11.74 \\
8.37\end{array}$ & $\begin{array}{r}11.24 \\
9.12\end{array}$ & $\begin{array}{r}11.25 \\
8.86\end{array}$ & $\begin{array}{l}0.95 \mathrm{~ns} \\
(2 ; 39)\end{array}$ \\
\hline 4 & $\begin{array}{l}t \\
i_{1}\end{array}$ & $\begin{array}{l}9.65 \\
7.21\end{array}$ & $\begin{array}{l}9.53 \\
8.09\end{array}$ & $\begin{array}{l}9.99 \\
8.39\end{array}$ & $\begin{array}{l}3.56^{*} \\
(2 ; 63)\end{array}$ \\
\hline 5 & $\begin{array}{l}t \\
i_{1}\end{array}$ & $\begin{array}{l}8.89 \\
6.65\end{array}$ & $\begin{array}{l}8.83 \\
7.29\end{array}$ & $\begin{array}{l}9.23 \\
7.88\end{array}$ & $\begin{array}{l}6.47^{* *} \\
(2 ; 62)\end{array}$ \\
\hline-16 & $\begin{array}{l}t \\
i_{1}\end{array}$ & $\begin{array}{l}8.26 \\
6.50\end{array}$ & $\begin{array}{l}8.30 \\
7.28\end{array}$ & $\begin{array}{l}8.23 \\
7.49\end{array}$ & $\begin{array}{l}3.29^{*} \\
(2 ; 45)\end{array}$ \\
\hline 7 & $\begin{array}{l}t \\
i_{1}\end{array}$ & $\begin{array}{l}7.65 \\
6.12\end{array}$ & $\begin{array}{l}7.68 \\
6.27\end{array}$ & $\begin{array}{l}7.63 \\
6.81\end{array}$ & $\begin{array}{l}2.49 \mathrm{~ns} \\
(2 ; 49)\end{array}$ \\
\hline 8 & $\begin{array}{l}t \\
i_{1}\end{array}$ & $\begin{array}{l}6.61 \\
5.69\end{array}$ & $\begin{array}{l}6.00 \\
4.98\end{array}$ & $\begin{array}{l}6.57 \\
5.68\end{array}$ & $\begin{array}{l}1.96 \mathrm{~ns} \\
(2 ; 6)\end{array}$ \\
\hline
\end{tabular}

ns $P>0.05,{ }^{*} 0.01<P \leqslant 0.05,{ }^{* *} 0.001<P \leqslant 0.01,{ }^{* * *}$ $P \leqslant 0.001$. and $-/ 6$ showed significant differences at the 5 per cent level; in arms $1 \mathrm{~S}$ and $3 /$ - distance $i$ increased in heterozygotes but decreased again in fusion homozygotes; in chromosome B the pattern was reciprocal; in arms $1 \mathrm{~S}$ and $3 / 6$, and in chromosome 8 , the differences were not significant (Table 1).

Relation between the $i$ distance and chromosome length. The preceding analysis was carried out for each chromosome (or chromosome arm) separately. It would be desirable to demonstrate the effect of fusion $3 / 6$ in increasing $i$ by using a unique statistical test. However, in other chiasma distribution studies based on grasshoppers, a positive correlation between $i$ and the lengths of different chromosomes was observed (Southern, 1967a; Fox, 1973); this was also noticed in $L$. argentina for all three fusion karyotypes, together with the observation that fusion carriers are prone to show longer $i$ distances (Fig. 2). Hence an analysis of covariance was performed (chromosomal length being the concomitant variable) allowing the joint analyses of all chromosomes controlling variation due to regres-

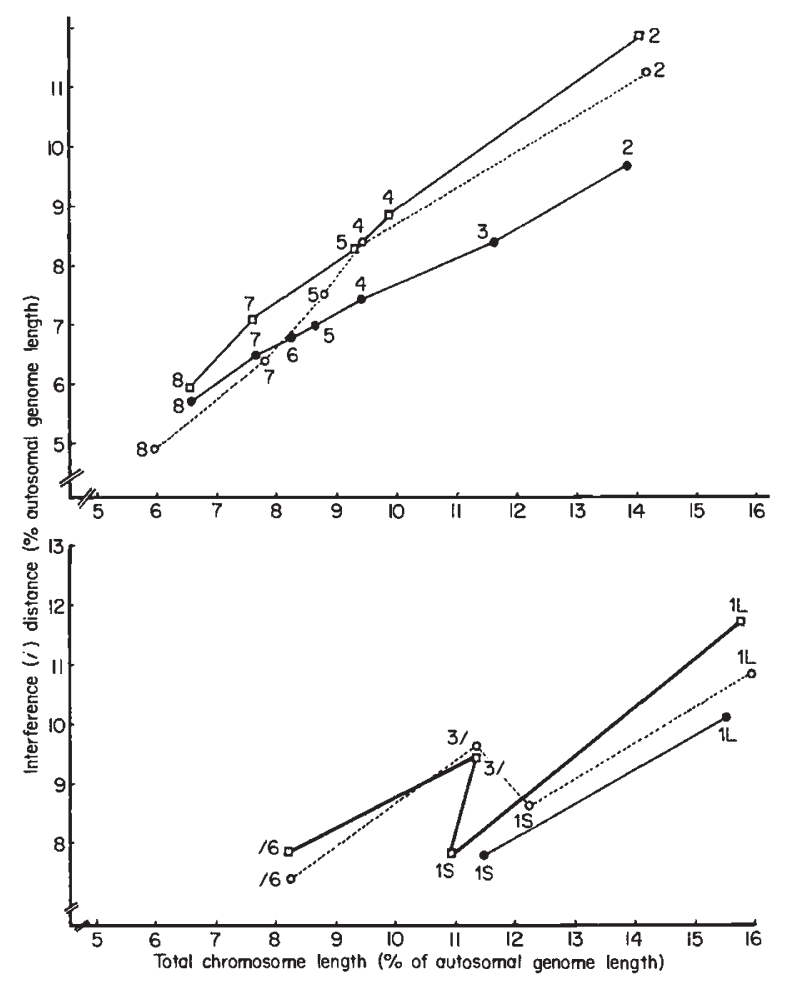

Fig. 2 Leptysma argentina. Interference distance $(i)$ represented versus total length $(t)$ of each chromosome or chromosome arm (distances and lengths are expressed as percentages of total autosomal length). (a) Telocentric chromosomes; (b) metacentric chromosomes. - basic homozygotes; ---O---: heterozygotes; - — - fusion homozygotes. 
Table 2 Analysis of covariance considering all chromosomes. Interference distance $\left(i_{1}\right)$ used as the main variable, and total chromosome length $(t)$ as concomitant variable, given that both are highly correlated.

$\mathrm{K}=$ karyotype, $r=$ correlation coefficient

\begin{tabular}{lllll}
\hline $\mathrm{K}$ & Mean $i_{1}$ & Mean $t$ & Regression equation & $r$ \\
\hline BB & 7.52 & 10.4177 & $i_{1}=0.5020 \mathrm{~T}+2.2902$ & 0.988 \\
BF & 8.05 & 10.47 & $i_{1}=0.5349 \mathrm{~T}+2.4539$ & 0.931 \\
FF & 8.4155 & 10.36 & $i_{1}=0.6647 \mathrm{~T}+1.5240$ & 0.941 \\
\hline
\end{tabular}

Difference between slopes is highly significant $\left(F_{2 ; 705}=16.42, P<0.001\right)$.

sion. This analysis revealed significant differences between the regression lines: that of fusion homozygotes $(b=0.6647)$ was significantly steeper than that of heterozygotes $(b=0.5349)$ and basic homozygotes $(b=0.5020)$ (Table 2, Fig. 2). Consequently the ANCOVA confirmed that fusion $3 / 6$ produced a dosage effect in increasing $i$, as stated before, not only in absolute values but also relative to its dependence on chromosome length.

The correlation between $i$ and chromosomal length was diversely interpreted, which implies divergent ideas of how chiasma interference acts on chiasma determination. Henderson (1963) and Southern (1967a) supported the view that $i$ determines where the second chiasma should form $(i$ being normally distributed). In this case, the correlation $i$ vs. chromosome length would be due to the differential intensity of interference in different chromosomes. On the contrary, Fox (1973) claimed that interference would act by determining where the second chiasma should not form, this distance being normally distributed. So, the length of the region where the formation of a new chiasma is precluded (say, where interference is complete) could be inferred from minimal $i$ distances $\left(i_{\text {min }}\right)$, $i$ being conditioned by a set of factors, such as the position of the first chiasma and the remnant length of the chromosome (Fox, 1973). This does not necessarily imply a normal distribution. In $S$. gregaria, $i_{\min }$ is constant over all chromosomes, irrespective of length, the correlation being due to greater residual length in longer chromosomes (Fox, 1973).

In the histogram of Fig. $3 i$ was represented as a function of chromosome length per chromosome (or arm) of $L$. argentina; $i$ distribution varies among chromosomes, the dispersion of data being very different from a normal distribution. On the other hand, $i_{\min } \mathrm{s}$ are approximately constant per karyotype, being longer in heterozygotes than in basic homozygotes and even longer in fusion homozygotes (Fig. 3). This seems to confirm that the dosage effect in increasing $i$ described in the section Differences between karyotypes, above, is due to a real and additive intensification of chiasma interference.

\section{Differential distance}

'Differential distance' was revealed to be negatively correlated with $i$ (Table 3 ). In each karyotype, $d$ distances are shorter in metacentric chromosomes than in telocentric ones, and much shorter in two-chiasmate bivalents than in one-chiasmate ones. When all three karyotypes were compared, a generalized trend towards a $d$ diminution in fusion carriers was noticed. The only exceptions to this pattern were arm $1 \mathrm{~L}$ and again chromosome 8 . In the remaining chromosomes, differences were significant at the 0.1 per cent (pairs 3, 6 and 2) or 5 per cent (1S, 1L, 5 and 7) level, or not significant at all ( 9 and 10). It is also worth noting that $d$ distances dropped drastically in chromosome 3 and 6 as a consequence of $3 / 6$ fusion (Table 3 ), due to the strong distal localization.

Distance $d$ correlation with chromosome length was not significant for standard homozygotes and for heterozygotes $(r=0.13$ and $r=-0.22$, respectively) but was inversely significant and negative for fusion homozygotes $(r=-0.75)$; this seems to be related to an increasing distal localization (shorter $d$ distances) in the metacentric (longest) chromosomes.

\section{Evidence from chiasma distribution histograms per bivalent}

In Fig. 4(a)-(d) chiasma distribution histograms are shown for each karyotype (BB, BF and FF) in arms $1 \mathrm{~L}, 1 \mathrm{~S}$ and also in chromosomes 2 and $3(3 /-)$ with 1 and 2 chiasmata, respectively. It is evident there is a marked proximal-distal localization in fusion $3 / 6$ carriers, due to enhanced interference (distance $d$ being negatively correlated with $i$ ). This fact is shown in chromosome 2, where an $i$ increase is reflected in a proximal chiasma repositioning toward centromeric regions, as well as in medium pairs (with the exception of chromosome 3 and 6 , due to fusion $3 / 6$ which distorts this pattern). In both fused chromosomes, the drop in chiasma frequency is so abrupt that it cannot be explained by an increase in $i$ only, given that shorter chromosomes $(4,5$ and 7$)$ show higher chiasma counts than arms $3 /$ - and $-/ 6$ separately.

In Table 4 average chiasma frequencies per bivalent per karyotype are shown; here it is evident that chiasma frequency differences between karyotypes are not significant in telocentric chromosomes but are significant in chromosome 1 (1L and $1 \mathrm{~S})$ and, of 

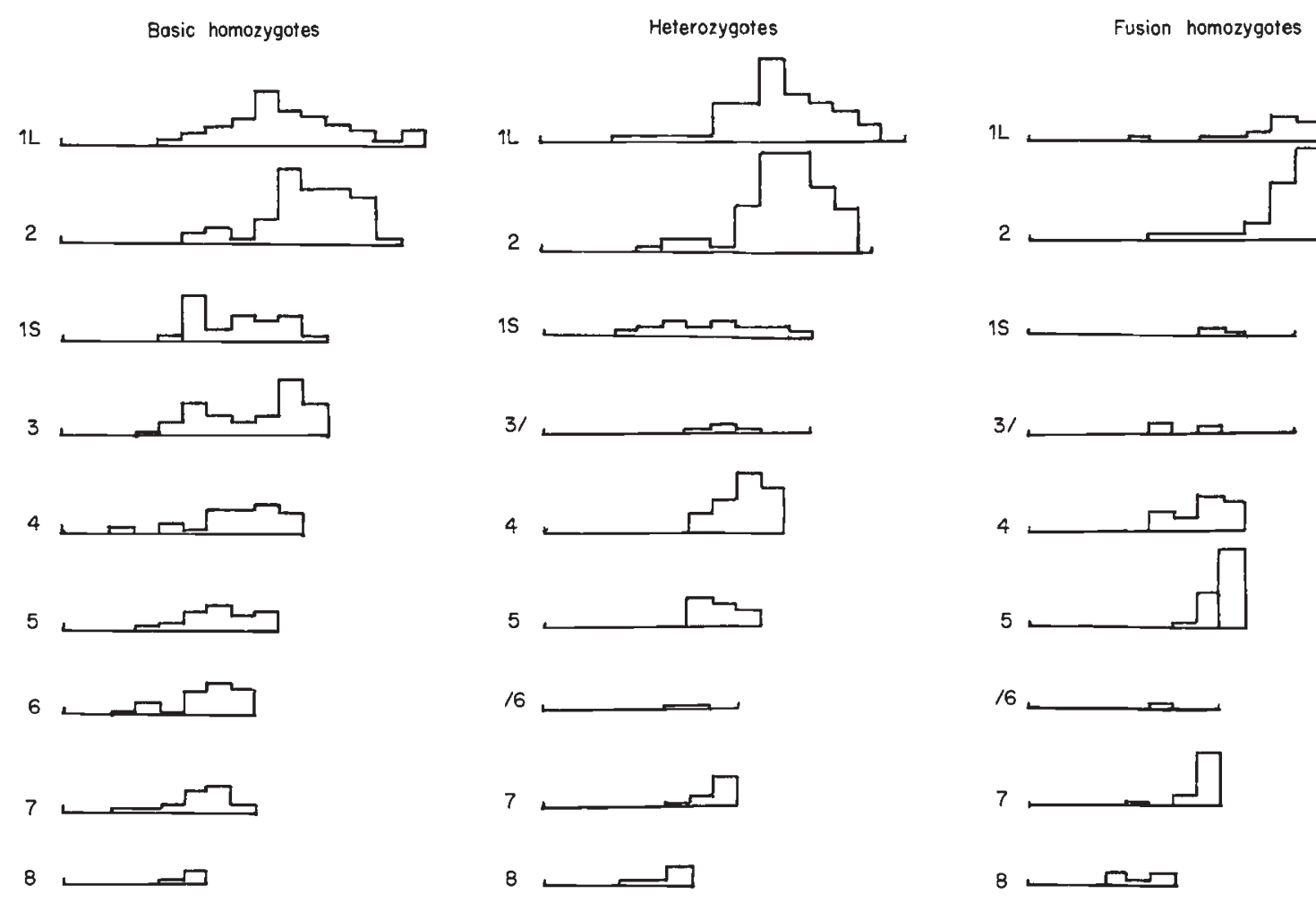

Fig. 3 Leptysma argentina. Distribution of interference distance $(i)$ along each chromosome or chromosome arm for all three karyotypes of fusion $3 / 6$ (telomeres to the extreme left). Note: the increase of interference distances in fusion carriers (especially in homozygotes), the low frequency of two chiasmate bivalents in the arms of metacentrics, and the constancy that minimal interference distance displays among all chromosomes (or chromosome arms) within each karyotype.

course, in fused chromosomes 3 and 6. Obviously, the original hypothesis (see above) which predicted that an increase in $i$ would cause a decrease of chiasma frequency in all chromosomes, is insufficient. According to this hypothesis, if chiasma frequency were plotted against chromosome length there should be three parallel lines representing, from top to bottom, BB, BF and FF points. The data, however, reveal that telocentric lines are not only parallel but superimpose, as if fusion $3 / 6$ had no effect on chiasma frequency. However, in metacentrics (which are separately represented) differences are evident: not only does metacentric 1 of standard homozygotes form a line below that of the telocentric chromosomes but also fusion $3 / 6$ seems to have elicited an abrupt decrease in chiasma frequency of both metacentric chromosomes (Fig. 5). Such behaviour suggests the operation of interference across the centromere, which was not considered at the first approach.

\section{Interference across the centromere}

As mentioned previously, earlier work ruled out the existence of interference across the centromere in Orthopterans; Southern (1967a) supposedly demon- strated its non-existence by means of statistical analyses whose validity will be discussed below, and other authors (e.g. Hultén, 1974; Arana, et al., 1980; Colombo, 1987, 1990b) accepted uncritically this point of view. However, the operation of interference across the centromere has been demonstrated in several organisms, such as Culex pipiens (Callan \& Montalenti, 1947), Dicranomya trinotata, Forficularia auricularia and Asellus aquaticus (John \& Lewis, 1965) and thereafter in the grasshopper Chorthippus brunneus (Laurie, 1980), where it was apparent that chiasma position in one arm of the metacentric influenced chiasma position in the other. To clarify this point, Southern (1967a) studied the correlation between chiasma frequency in the long arm vs. chiasma frequency in the short arm in four species of 'truxaline' grasshopper (whose chromosome pairs 1 to 3 are metacentric). A negative correlation, according to Southern, would have suggested trans-centromere interference. However, the results were erratic and not significant; Southern (1967a) concluded that interference does not act beyond the centromere. According to our criteria, however, this analysis is not enough to rule out the operation of trans-centromere interference; the best way of assessing it would be by veri- 
Table 3 Total $(t)$ and differential $(d)$ distances for onechiasmate $\left(1 \mathrm{X}^{\mathrm{a}}\right)$ and two-chiasmate $\left(2 \mathrm{X}^{\mathrm{ta}}\right)$ bivalents, expressed as percentages of total autosomic genome length. Means of 10 cells from 8,10 and 9 standard homozygotes, heterozygotes and fusion homozygotes, respectively, for fusion 3/6 of Leptysma argentina. An analysis of variance comparing mean interference distances for each karyotype was carried out. Variance ratios $(F)$ and significance levels are shown

\begin{tabular}{|c|c|c|c|c|c|}
\hline & & \multicolumn{3}{|c|}{ Karyotype } & \\
\hline & & $\mathrm{BB}$ & $\mathrm{BF}$ & FF & \\
\hline $1 \mathrm{~L}$ & $\begin{array}{l}t \\
d\left(1 \mathrm{X}^{\mathrm{a}}\right) \\
d\left(2 \mathrm{X}^{\mathrm{a}}\right)\end{array}$ & $\begin{array}{r}15.56 \\
1.60 \\
0.39\end{array}$ & $\begin{array}{r}16.19 \\
2.14 \\
0.29\end{array}$ & $\begin{array}{r}15.50 \\
0.44 \\
0.21\end{array}$ & $\begin{array}{l}3.59^{*} \\
0.67 \mathrm{~ns}\end{array}$ \\
\hline 2 & $\begin{array}{l}t \\
d\left(1 X^{\mathrm{a}}\right) \\
d\left(2 \mathrm{X}^{\mathrm{ta}}\right)\end{array}$ & $\begin{array}{r}13.97 \\
4.45 \\
0.38\end{array}$ & $\begin{array}{r}14.11 \\
2.11 \\
0.24\end{array}$ & $\begin{array}{r}13.93 \\
1.03 \\
0.00\end{array}$ & $\begin{array}{c}28.35^{* * *} \\
6.58^{* *}\end{array}$ \\
\hline $1 \mathrm{~S}$ & $\begin{array}{l}t \\
d\left(1 \mathrm{X}^{\mathrm{a}}\right) \\
d\left(2 \mathrm{X}^{\mathrm{ta}}\right)\end{array}$ & $\begin{array}{r}11.43 \\
1.34 \\
0.36\end{array}$ & $\begin{array}{r}12.35 \\
0.87 \\
0.00\end{array}$ & $\begin{array}{r}10.98 \\
0.36 \\
0.00\end{array}$ & $\underbrace{3.65^{*}}$ \\
\hline $3 /-$ & $\begin{array}{l}t \\
d\left(1 \mathrm{X}^{\mathrm{a}}\right) \\
d\left(2 \mathrm{X}^{\mathrm{ta}}\right)\end{array}$ & $\begin{array}{r}11.74 \\
5.82 \\
0.38\end{array}$ & $\begin{array}{r}11.24 \\
1.18 \\
0.24\end{array}$ & $\begin{array}{r}11.25 \\
0.75 \\
0.00\end{array}$ & $\begin{array}{l}20.91^{* * *} \\
-\end{array}$ \\
\hline 4 & $\begin{array}{l}t \\
d\left(1 \mathrm{X}^{\mathrm{a}}\right) \\
d\left(2 \mathrm{X}^{\mathrm{ta}}\right)\end{array}$ & $\begin{array}{l}9.65 \\
4.98 \\
0.54\end{array}$ & $\begin{array}{l}9.53 \\
2.93 \\
0.00\end{array}$ & $\begin{array}{l}9.99 \\
1.23 \\
0.00\end{array}$ & $\begin{array}{l}4.32 * \\
-\end{array}$ \\
\hline 5 & $\begin{array}{l}t \\
d\left(1 \mathrm{X}^{\mathrm{a}}\right) \\
d\left(2 \mathrm{X}^{\mathrm{ta}}\right)\end{array}$ & $\begin{array}{l}8.89 \\
5.67 \\
0.18\end{array}$ & $\begin{array}{l}8.83 \\
2.72 \\
0.00\end{array}$ & $\begin{array}{l}9.23 \\
1.81 \\
0.00\end{array}$ & $\begin{array}{l}3.48^{*} \\
-\end{array}$ \\
\hline-16 & $\begin{array}{l}t \\
d\left(1 \mathrm{X}^{\mathrm{a}}\right) \\
d\left(2 \mathrm{X}^{\mathrm{ta}}\right)\end{array}$ & $\begin{array}{l}8.26 \\
1.32 \\
0.00\end{array}$ & $\begin{array}{l}8.30 \\
0.76 \\
0.00\end{array}$ & $\begin{array}{l}8.23 \\
0.68 \\
0.00\end{array}$ & $\begin{array}{l}34.87^{* * *} \\
--\end{array}$ \\
\hline 7 & $\begin{array}{l}t \\
d\left(1 \mathrm{X}^{\mathrm{a}}\right) \\
d\left(2 \mathrm{X}^{\mathrm{ta}}\right)\end{array}$ & $\begin{array}{l}7.65 \\
3.09 \\
0.18\end{array}$ & $\begin{array}{l}7.68 \\
1.84 \\
0.00\end{array}$ & $\begin{array}{l}7.63 \\
1.82 \\
0.00\end{array}$ & $\underline{3}^{3.44}$ \\
\hline 8 & $\begin{array}{l}t \\
d\left(1 \mathrm{X}^{\mathrm{a}}\right) \\
d\left(2 \mathrm{X}^{\mathrm{ta}}\right)\end{array}$ & $\begin{array}{l}6.61 \\
2.71 \\
0.00\end{array}$ & $\begin{array}{l}6.00 \\
3.37 \\
0.00\end{array}$ & $\begin{array}{l}6.57 \\
2.59 \\
0.00\end{array}$ & $\begin{array}{l}2.9 \mathrm{~ns} \\
-\end{array}$ \\
\hline 9 & ${ }^{t} d\left(1 \mathrm{X}^{\mathrm{a}}\right)$ & $\begin{array}{l}4.65 \\
1.48\end{array}$ & $\begin{array}{l}5.78 \\
1.28\end{array}$ & $\begin{array}{l}5.41 \\
1.51\end{array}$ & $0.10 \mathrm{~ns}$ \\
\hline
\end{tabular}

(b) Correlation coefficients of $d$ and $i$ in two-chiasmate bivalents: (i) Basic homozygotes: $r=-0.2711, P=0.0461$, (ii) Heterozygotes: $r=-0.4312, P=0.0032$, (iii) Fusion homozygotes: $r=-0.5020, P=0.0012$.ns: $P>0.05$; *: $0.01<P \leqslant 0.05$; **: $0.001<P \leqslant 0.01$; ***: $P \leqslant 0.001$.

fying negative correlations between residual lengths $(r)$ in each arm of the metacentrics (Laurie, 1980). In fact, if interference acts across the centromere, then there should be a 'distance of interference across the centro- mere' (analogous to $i$ ) given by the sum of both residual lengths (termed here $r_{1}$ and $r_{2}$ ). Of course, the caveat that was put forward for distance $i$ is valid for $r_{1}+r_{2}$; these distances would express genuine chiasma interference only if they were short. If distances were long, the possibility should be considered that neither chiasma interacted at all, and that there is an approximately constant minimal distance (as in the case of $i_{\min }$ ), where the formation of another chiasma is entirely precluded. In this case, longer $r$ distances on one side of the centromere ought to be accompanied by shorter $r$ distances on the other, therefore giving negative correlation between both distances. If all chromosomes are considered (even those with long $r$ distances), both chiasmata will not necessarily interact, and hence correlations might not be significant; correlations would become more and more significant, by contrast, with increasingly shorter $r_{1}+r_{2}$ distances. Finally, if $r_{1}+r_{2}$ were indeed an $i$ distance, it would be increased in carriers of fusion $3 / 6$.

This analysis was carried out for the metacentric chromosome 1 , and the results are given in Table 5 . Correlations between $r_{1}$ and $r_{2}$ (where $r_{1}$ is the residual length of the arm $1 \mathrm{~L}$ and $r_{2}$ is that of $1 \mathrm{~S}$ ) were not significant when chromosome 1 was considered in the three karyotypes in all cells. However, when only distances shorter than 25 (in total autosomal length percentage) were used for $r_{1}+r_{2}$, negative correlations began to appear; it became apparent not only that repulsion is stronger with decreasing $r_{1}+r_{2}$ values, but also that there seems to be a dosage effect of fusion $3 / 6$ with increasing $r_{1}+r_{2}$ distances (Fig. 4c). This suggests strongly the operation of interference across the centromere.

Therefore, in our opinion, it is possible that both intra- and interchromosome effects are a consequence of an intensification in chiasma interference for carriers of fusion 3/6. This increase of interference would have two main consequences: (i) in telocentrics, a displacement of chiasmata towards the telomeres which would cause a proximal-distal chiasma distribution pattern with no change in chiasma frequency; and (ii) chiasma frequency would instead be changed in metacentrics due to the operation of trans-centromere interference. This fact would cause a proximal chiasma frequency decrease in bivalent 1 , and their complete suppression in bivalent $3 / 6$ due to its shorter size. Note that the arm is (approximately the same length as the arm 3/-) also displays proximal and interstitial chiasma suppression in fusion carriers.

\section{On the origin of fusion $3 / 6$}

The problem remains of how fusion $3 / 6$ became polymorphic. The doctrine requires that such a rearrange- 
ment, which may show negative heterosis, must have experienced a strong positive selection at its origin (due to some hypothetical advantage of their carriers) to override it. Of course, we only know the present effects of fusion 3/6: the increase in interference (that is adaptive) and the body size effect (that is suspected to be adaptive, Colombo 1989a, b, 1990a). If an increase in $i$ is not a direct effect of fusion, it should arise by selection against ill-oriented trivalents. The genes responsible for this change would cluster in the consequent
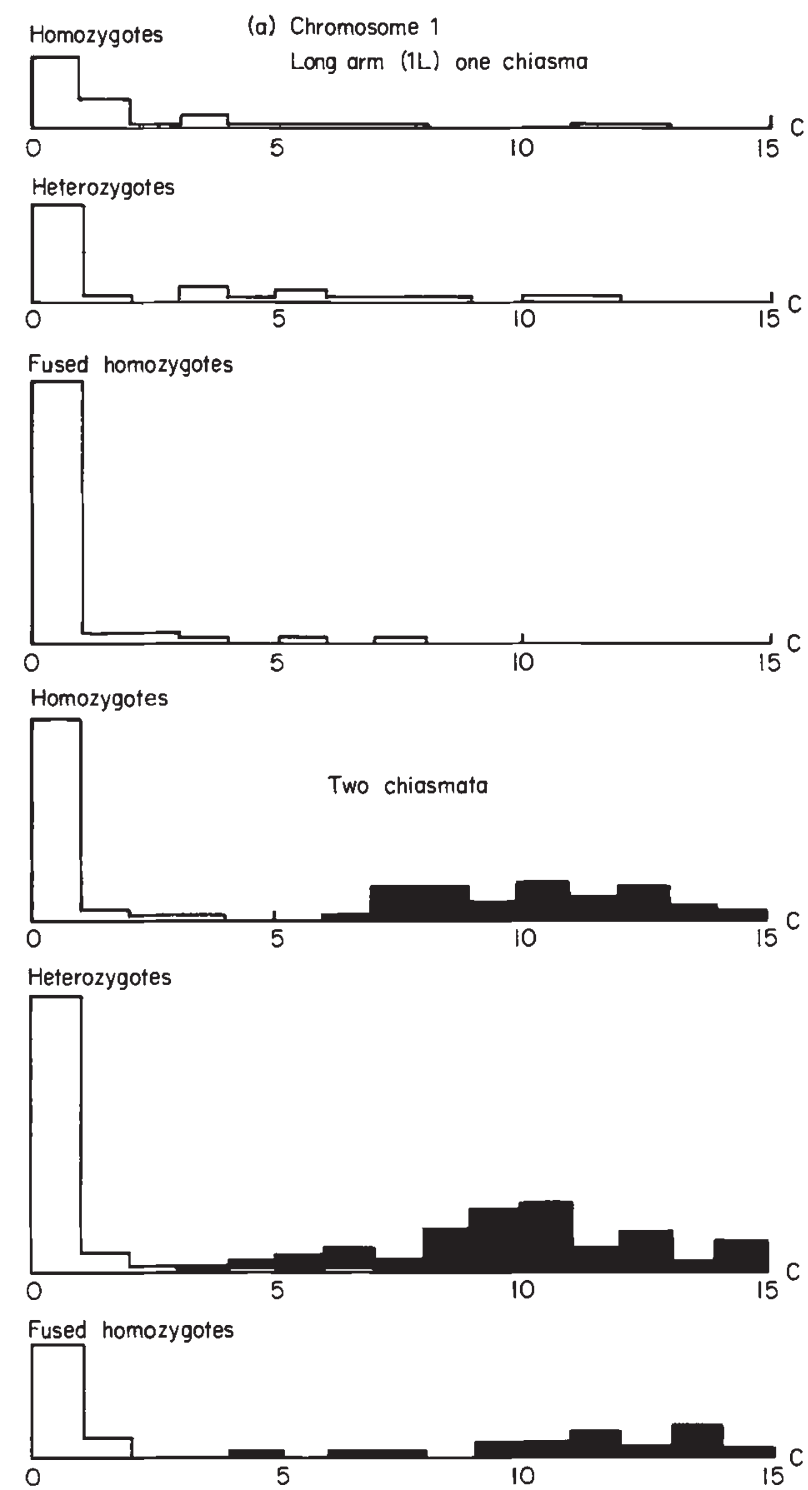

metacentric chromosome. Fusion carriers should have had a selective advantage to override the negative heterosis, and the body size effect is a good candidate for this advantage (Colombo, 1989a). The reverse argument could be set out if the interference increase was a direct effect of the fusion; however, the fact that spontaneous, newly arisen centric fusions (i.e. without previous selective history) never attain the degree of redistribution observed in the polymorphic state - like those observed in fusion $3 / 6$ of $L$. argentina and the

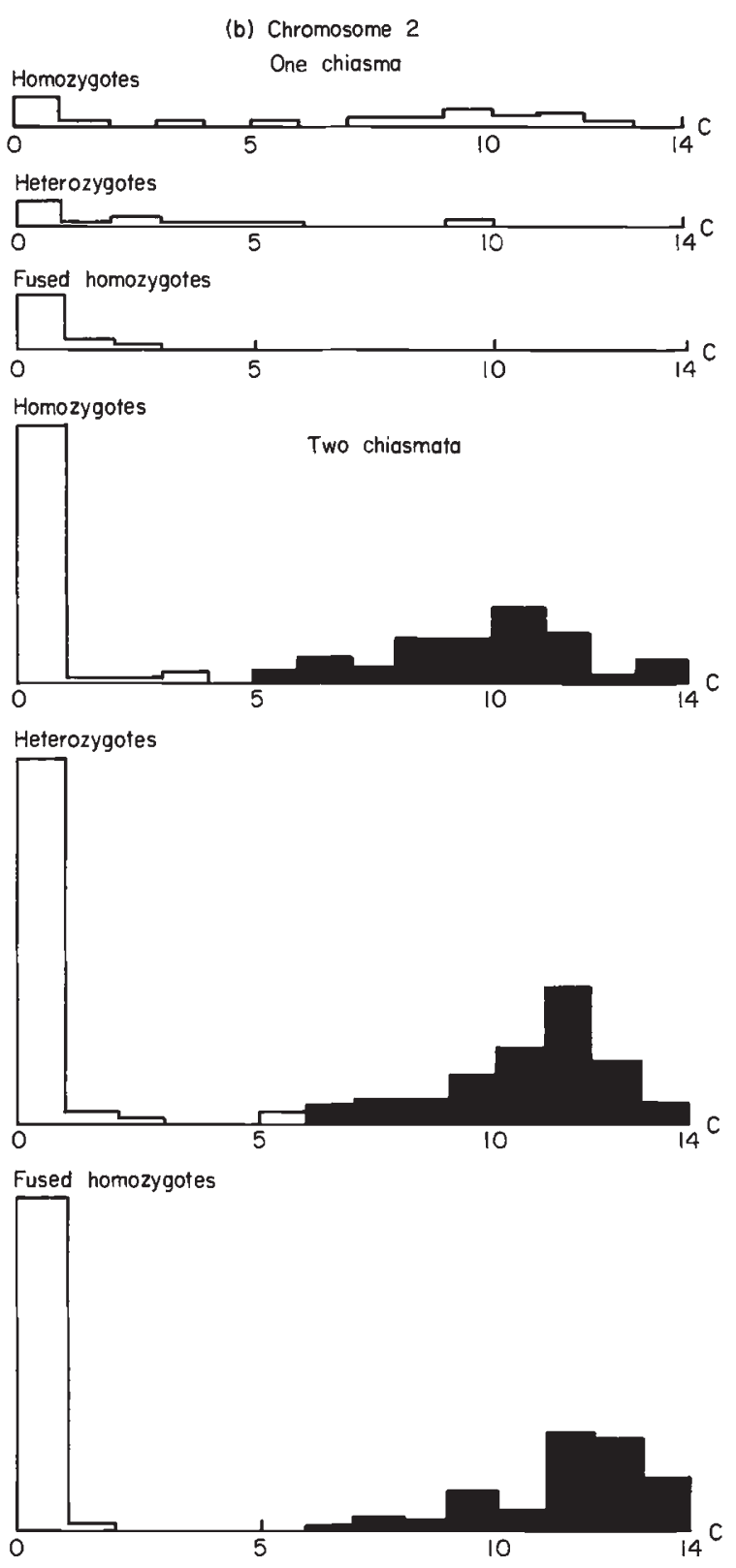

Fig. 4 Leptysma argentina. Chiasma distribution in chromosomes (or chromosome arms) (a) 1L, (b) 2, (c) 1S and (d) 3 (3/-) for bivalents with one and two chiasmata in each one of all three fusion karyotypes. In the graphs that represent two-chiasmate chromosomes, black bars correspond to the position of the second chiasma. Note a marked proximal-distal pattern among fusion carriers (especially in fusion homozygotes). Numbers in abscissa are chromosome lengths expressed as a percentage of total autosomal length. $\mathrm{C}=$ centromeres; telomeres to the extreme left. 
(c) Chromosome 1-Short arm (1S)

Homozygotes

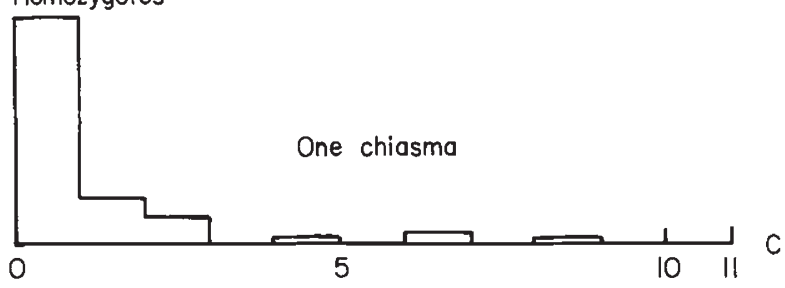

Heterozygotes

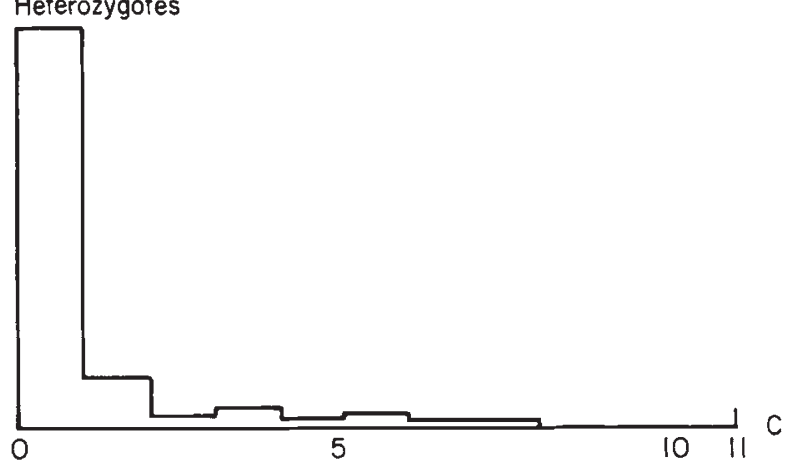

Fused homozygotes

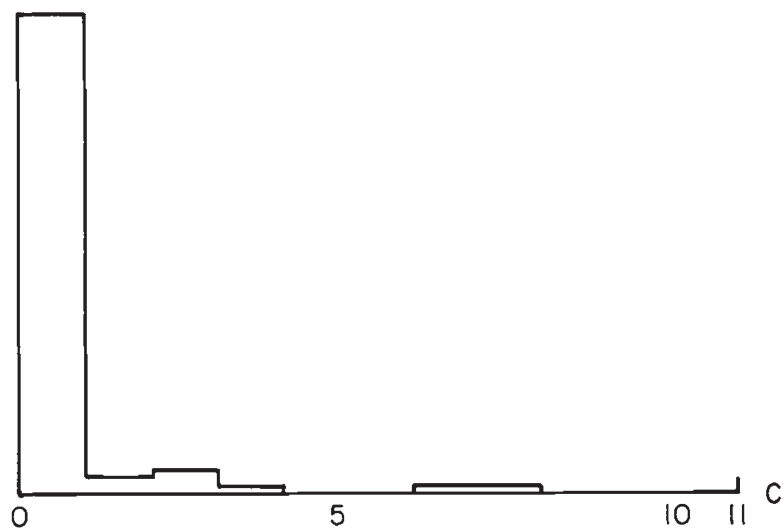

Homozygotes

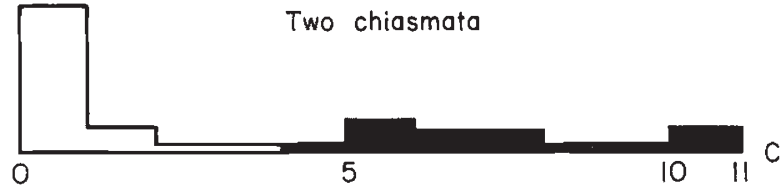

Heterozygotes

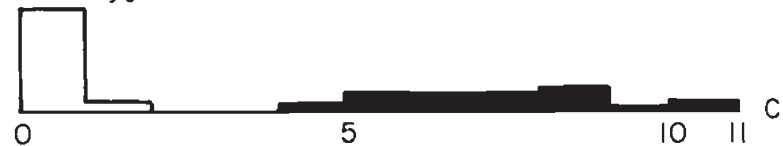

Fused homozygotes

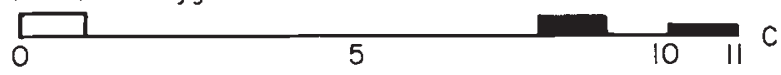

(d) Chromosome 3

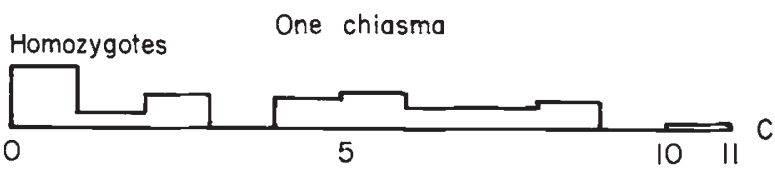

Heterozygotes

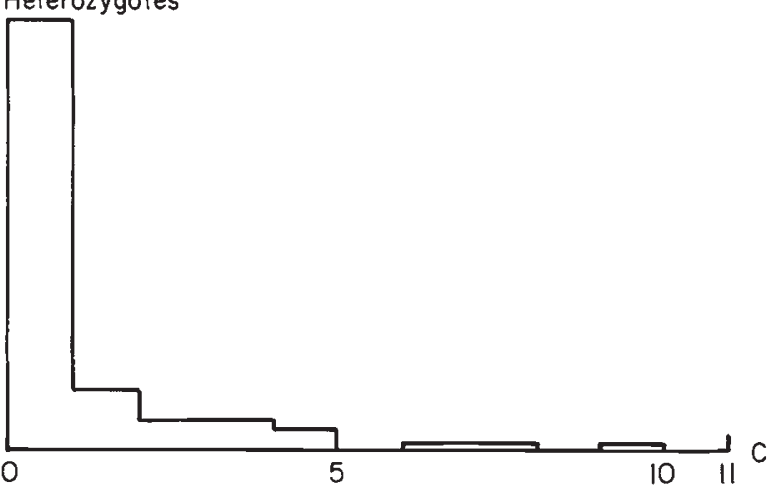

Basic homozygotes

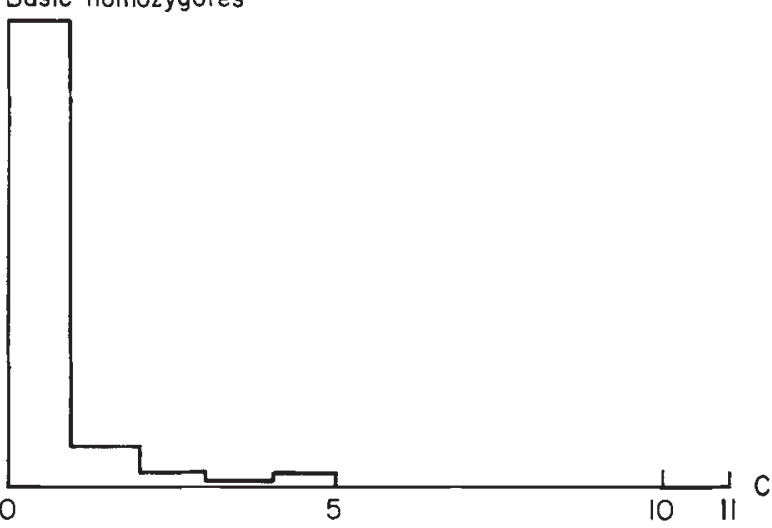

Homozygotes

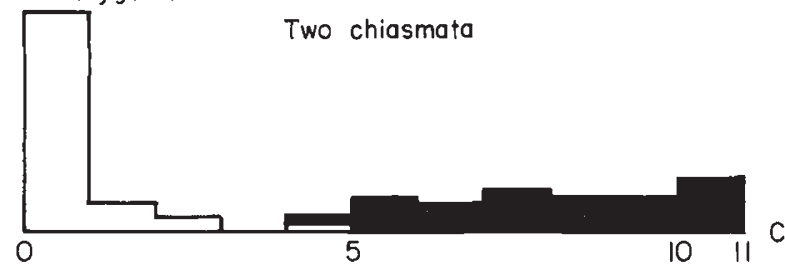

Heterozygotes

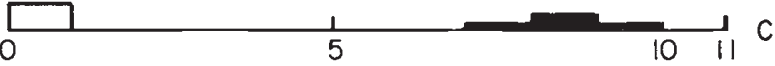

Fusion homozygotes

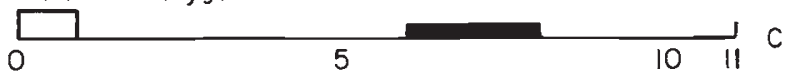

Fig. 4 Continued

various fusion metacentrics of Dichroplus pratensis described by Bidau $(1984,1990)$ - leads us to favour the hypothesis of $i$ increasing as a result of adaptation to the polymorphic state (Southern, 1967b; Polani, 1972; Peters, 1982; Teoh \& Young, 1983; López
Fernández et al., 1984; Vilardi, 1984; Colombo, 1987; Remis, 1990).

Bidau (1990) argues that this body of evidence is insufficient, because these cases are 'a scanty amount indeed' of all fusions that occur spontaneously in 
Table 4 Mean chiasma frequencies per chromosome (or chromosome arm) for each karyotype. Under the title 'total metacentrics' pairs 3 and 6 of basic homozygotes were included, for the sake of comparison

\begin{tabular}{|c|c|c|c|}
\hline & \multicolumn{3}{|c|}{ Karyotype } \\
\hline & $\mathrm{BB}$ & $\mathrm{BF}$ & $\mathrm{FF}$ \\
\hline $1 \mathrm{~L}$ & 1.60 & 1.67 & 1.29 \\
\hline $1 \mathrm{~S}$ & 1.34 & 1.16 & 1.03 \\
\hline 2 & 1.76 & 1.86 & 1.83 \\
\hline $3 /-$ & 1.53 & 1.04 & 1.05 \\
\hline 4 & 1.31 & 1.35 & 1.25 \\
\hline 5 & 1.30 & 1.18 & 1.32 \\
\hline-16 & 1.36 & 1.02 & 1.01 \\
\hline 7 & 1.27 & 1.15 & 1.24 \\
\hline 8 & 1.05 & 1.03 & 1.06 \\
\hline 9 & 1.00 & 1.00 & 1.00 \\
\hline 10 & 1.00 & 1.00 & 1.00 \\
\hline Total & 14.52 & 13.46 & 13.11 \\
\hline Total $(-3+6)$ & 11.63 & 11.40 & 11.05 \\
\hline $\begin{array}{l}\text { Total } \\
\text { metacentric }\end{array}$ & 5.83 & 4.89 & 4.38 \\
\hline $\begin{array}{l}\text { Total } \\
\quad \begin{array}{l}\text { telocentric } \\
\quad(-3+6)\end{array}\end{array}$ & 8.49 & 8.57 & 8.73 \\
\hline
\end{tabular}

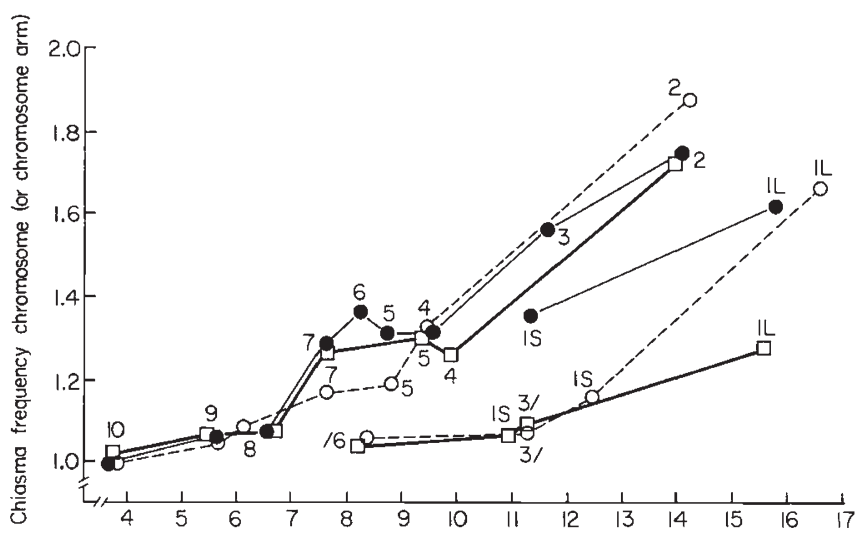

Chromosome (or chromosome arm) length as a percentage of total autosomal length

Fig. 5 Leptysma argentina. Chiasma frequency in each chromosome (or chromosome arm) for all three fusion $3 / 6$ karyotypes plotted against chromosome length (expressed as a percentage of total autosomal length. Metacentric chromosome arms are represented separately (lower graph) from telocentrics (upper graph) because their behaviour is different; see a strikingly similar pattern in Southern (1967). References as in Fig. 2.

nature. However, the examples of non-chiasma repatterning after spontaneous centric fusions are consistent, albeit scanty; moreover, the examples of really extensive repatterning of chiasmata as a consequence
Table 5 Correlation coefficients between $r_{1}$ (1L residual distance) and $r_{2}$ (1S residual distance) for different values of $r_{1}+r_{2}$

\begin{tabular}{llll}
\hline & \multicolumn{2}{l}{ Karyotype } \\
\cline { 2 - 4 }$r_{1}+r_{2}$ & BB & BF & FF \\
\hline$\leq 30$ & -0.07 & -0.024 & -0.02 \\
$\leq 25$ & -0.10 & -0.13 & -0.30 \\
$\leq 20$ & -0.20 & -0.35 & -0.63 \\
$\leq 18$ & -0.34 & -0.50 & -0.57 \\
$\leq 15$ & -0.42 & -0.69 & -0.74 \\
$\leq 12$ & -0.45 & -0.89 & -0.89 \\
$\leq 10$ & -0.28 & -0.86 & -1 \\
\hline
\end{tabular}

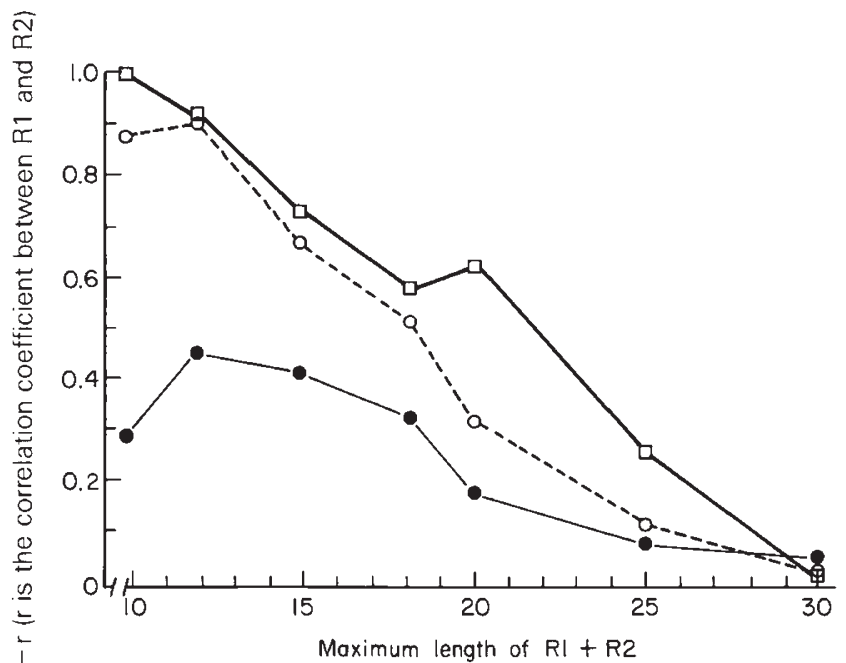

Fig. 6 Leptysma argentina. Correlation coefficient (in absolute values) between $r_{1}$, and $r_{2}$ (see explanation in text).

of interchanges and fissions comparable to those observed in polymorphic metacentrics are lacking. However, in our opinion, the overwhelming number of species with fixed fusions where chiasma studies were carried out (Callan \& Montalenti, 1947; John \& Lewis, 1965; Southern, 1967a; John \& Freeman, 1975; Hultén, 1974; Shaw \& Knowles, 1976; Maudlin \& Evans, 1980; Laurie \& Jones, 1981; Coates \& Shaw, 1982 (see Sybenga, 1975 and Jones, 1987 for a review) provides more significant evidence. None of these studies revealed such an extensive repatterning (virtual proximal and interstitial chiasma suppression) as that observed in polymorphic fusions, probably because they do not 'need' a stable trivalent orientation (albeit in some cases a slight restriction in chiasma frequency and/or position was noticed - possibly explainable in terms of across-centromere interference or pairing disturbance). 
As an alternative hypothesis, Bidau (1990) advanced a speculative model to explain this effect on the basis of modifications in pairing; unfortunately, it does not explain why fixed metacentrics (as in the case of metacentric 1 of $L$. argentina, see above also) are much less affected than polymorphic ones - which are the only ones to have extensive chiasma repatterning. Finally, these pairing modifications, albeit possible, were not observed in either $L$. argentina or in $D$. pratensis, and in consequence the factual basis for this argument in both species is nil.

In our opinion, the solution to this dilemma should be looked for in natural populations. Surprisingly, the best example found by us in the literature was provided by Bidau (1990). In this work, fusion homozygotes of $D$. pratensis proceeding from two populations, one of them with metacentrics $1 / 2,3 / 4$ and $5 / 6$ in polymorphic condition and the other with the same metacentrics but in fixed state, were compared with respect to chiasma frequency and position in these metacentric bivalents. In the polymorphic population, fusion homozygotes displayed the usual restrictions for proximal and interstitial chiasma formation, whereas in the 'fixed' population (called ' $C$ ') proximal chiasma frequency in metacentrics arose in a significant fashion. Such a result can only be interpreted in terms of relaxed selection against proximal and interstitial chiasmata in fixed metacentrics, resulting in a reversion of chiasma behaviour. So seems Bidau to interpret his results: '... while a pronounced reduction in chiasma frequency (especially of the proximal type) is expected in polymorphic populations due to the 'need' of stabilizing trivalent orientation, this restriction need not operate in populations where the fusions are fixed'. If chiasma redistribution is a direct effect of the fusion, no restriction nor 'mechanical needs' are either to be found or reverted; if chiasma redistribution is reverted, as in the quoted case (Bidau, 1990), to speak about relaxed restrictions is to accept the role of selection acting against proximal and interstitial chiasmata in the trivalents. Of course the best proof of it would be to study a newly arisen fusion, perhaps followed by a long-term study of their behaviour; meanwhile, population 'C' of D. pratensis (Bidau, 1990) is, in our opinion, an excellent proof for the role of selection in repatterning chiasma frequency and position as a response to selective pressures set out by polymorphic conditions.

\section{Concluding statement}

It is possible that, despite the external similarity of the two cases, the differences between $L$. argentina and $D$. pratensis involve more clues that the number of fusions concerned. In L. argentina the effects are intra- as well as interchromosomal; in $D$. pratensis they are only intrachromosomal. This difference is very important: in $D$. pratensis a direct effect of fusions could have caused chiasma repatterning, but in L. argentina this repatterning also affects the rest of the genome. Indeed, acrosscentromere interference, which we have shown in this work to be operative in L. argentina, is in fact an example of a direct effect caused by a fusion that may have been a slight pre-adaptation to the maintenance of the polymorphism, and perhaps occurred in both species. The question is to what extent this pre-adaptation was enough; perhaps in D. pratensis trans-centromere interference, if it existed, would have served as a primer - definitive in some cases, especially in shorter metacentrics - to avoid intense negative heterosis and finally improved by selection. In $L$. argentina this obviously did not suffice, and a second effect such as interference intensification in fusion carriers had to be developed in order to ensure a proper segregation of trivalents; here selection probably acted on the genes that control interference intensity, which we suppose are linked to metacentric $3 / 6$.

\section{Acknowledgements}

I wish to express my gratitude to Dr J. C. Vilardi, who kindly suggested this work and criticized several flaws in the manuscript; to my colleagues Drs Viviana Confalonieri and Isabel Remis for helpful discussions and valuable suggestions, to Prof. Dr Juan H. Hunziker for encouragement and critical reading of the manuscript and to the National Board of Natural Parks (Dirección Nacional de Parques Naturales, Argentina) for allowing sample collection in the National Park 'El Palmar'. The taxonomical identification of the material was made by the entomologist Dr Ricardo Ronderos, to whom the author is very grateful. The author is also grateful to the anonymous reviewers whose criticisms improved the manuscript. Financial support from the Consejo Nacional de Investigaciones Científicas y Técnicas (CONICET) and the Subsecretaria de Ciencia y Técnica is gratefully acknowledged.

\section{References}

ARANA, P., SANTOS, J. L. AND GIRÁldEZ, R. 1980. Chiasma interference and centromere coorientation in a spontaneous translocation heterozygote of Euchorthippus pulvinatus gallicus (Acrididae: Orthoptera). Chromosoma, 78, 327-340.

BIDAU, C. J. 1984. Estudios citogenéticos en Orthoptera de Sudamérica. Ph.D. Thesis, Universidad de Buenos Aires. BIDAU, C. J. 1990. The complex Robertsonian system of Dichroplus pratensis (Melanoplinae, Acrididae). II. Effects 
of the fusion polymorphism on chiasma frequency and distribution. Heredity, 64, 145-159.

BIDAU, C. J., AND HASSON, E. R. 1984. Population cytology of Leptysma argentina Bruner (Leptysminae: Acrididae). Genetica, 62, 161-175.

BIDAU, C. J. AND MIROL, P. 1988. Orientation and segregation of Robertsonian trivalents in Dichroplus pratensis (Acrididae). Genome, 30, 947-955.

CALLAN, H. G. AND MONTALENTI, G. 1947. Chiasma interference in mosquitoes. J. Genet., 48, 119-134.

COATES, D. J. AND SHAW, D. D. 1982. The chromosome complement of reproductive isolation in the grasshopper Caledia captiva. 1. Meiotic analysis of chiasma distribution patterns in two chromosomal taxa and their $F_{1}$ hybrids. Chromosoma, 46, 173-179.

CоLомBO, P. C. 1987. Effects of centric fusions on chiasma frequency and position in Leptysma argentina (Acrididae: Orthoptera). I. Spontaneous and stable polymorphic centric fusions. Genetica, 71, 171-179.

соцомво, P. C. 1989a. Chromosome polymorphisms affecting recombination and exophenotypic traits in Leptysma argentina (Orthoptera). Heredity, 62, 289-299.

соцомво, Р. C. 1989b. Estudios citogenéticos poblacionales en la subfamilia Leptysminae (Acrididae: Orthoptera). Ph.D. Thesis, Universidad de Buenos Aires.

соLомво, Р. с. 1989c. Effects of B-chromosome on recombination in Cylindrotettix obscurus (Leptysminae: Acrididae). Caryologia, 42, 65-79.

соцомво, Р. с. 1990a. Polimorfismos cromosómicos en ortópteros. Actas del I Cong. Nac. Entomol. (Tucumán, Argentina): 95-108.

CoLomBo, P. c. 1990b. Effects of centric fusions on chiasma frequency and position in Leptysma argentina (Acrididae: Orthoptera). II. Intra- and interchromosome effects. Caryologia , 43, 131-147.

FOX, D. P. 1973. The control of chiasma distribution in the locust, Schistocerca gregaria (Forskal). Chromosoma, 43, 289-328.

GROPP, A. AND WINKING, H. 1981. Robertsonian translocations: cytology, meiosis, segregation patterns and biological consequences of heterozygosis. In: Berry, R. J. (ed.), Biology of the House Mouse. Academic Press, New YorkLondon.

HENDERSON, S. A. 1963. Chiasma distribution at diplotene in a locust. Heredity, 18, 173-190.

HEWITT, G. M. 1967. An interchange that raises chiasma frequency. Chromosoma, 21, 285-295.

HewITT, G. M. 1979. Animal Cytogenetics. Vol. 3. Insecta 1. Orthoptera. Gebrüder Bornträger. Berlin-Stuttgart.

hulTÉN, M. 1974. Chiasma distribution at diakinesis in the normal human male. Hereditas, 76, 55-78.

JoHN, в. 1983. The role of chromosomal change in the evolution of orthopteroid insects. In: A. K. Sharma \& A. M. Sharma (eds), Chromosomes in the evolution of Eukaryotic groups, Vol. 1, C.R.C. Press, Florida, pp. 1-114.

JOHN, B. AND FREEMAN, M. 1975. Causes and consequences of Robertsonian exchange. Chromosoma, 52, 123-136.
JOHN, B. AND LEWIS, K. R. 1965. The meiotic system. Protoplasmatologia $v 1 / F / 1$. Springer Verlag, Wien.

JONES, G. H. 1987. Chiasmata. In: P. Moens, (ed.) Meiosis. Academic Press, London.

LAURIE, D. 1980. Interindividual variation in chiasma frequency and chiasma distribution. $\mathrm{PhD}$. Thesis, University of Birmingham.

LAURIE, D. A. AND JONES, G. H. 1981. Inter-individual variation in chiasma distribution in Chorthippus brunneus (Orthoptera: Acrididae). Heredity, 47, 409-416.

LOPEZ FERNANDEZ, C., RUFAS, J. S., GARCIA DE LA VEGA, C. AND GosAlvez, J. 1984, Cytogenetic studies on Chorthippus jucundus (Fisch.) (Orthoptera). III. The meiotic consequences of a spontaneous centric fusion. Genetica, 63, 3-7.

MATHER, K. 1936. The determination of position in crossingover. I. Drosophila melanogaster. J. Genet., 33, 207-235.

MATHER, K. 1937. The determination of position in crossingover. II. The chromosome length-chiasma frequency relation. Cytologia Fujii Jubilee Vol., pp. 514-526.

MAUDLIN, I. AND EVANS, E. P. 1980. Chiasma distribution in mouse oocytes during diakinesis. Chromosoma, 80, 49-56.

PARKER, J. s. 1987. Increased chiasma frequency as a result of chromosome rearrangement. Heredity, 58, 87-94.

PARKER, J. S., PALMER, R. W., WHITEHORN, M. A. F. AND EDGAR, L. A. 1982. Chiasma frequency effects of structural chromosome change. Chromosoma, 85, 673-686.

PETERS, G. B. 1982. The recurrence of chromosome fusion in interpopulation hybrids of the grasshopper Atractomorpha similis. Chromosoma, 85, 323-347.

POLANI, P. E. 1972. Centromere localization at meiosis and the position of chiasmata in the male and female mouse. Chromosoma, 36, 343-374.

REMIS, M. I. 1990. Cytogenetic studies in Sinipta dalmani (Orthoptera: Acrididae). II. Effects of centric fusions on chiasma frequency and distribution. Gen. Sel. Evol., 22, 263-272.

SHAW, D. D. AND KNOWLES, G. R. 1976. Comparative chiasma analysis using a computerised optical digitiser. Chromosoma, 89, 103-127.

SOUTHERN, D. I. 1967a. Chiasma distribution in truxaline grasshoppers. Chromosoma, 22, 164-191.

SOUTHERN, D. I. $1967 \mathrm{~b}$. Spontaneous chromosome mutations in truxaline grasshoppers. Chromosoma, 22, 241-247.

sYBEnGA, J. 1975. Meiotic Configurations. Monogr. Theor. Appl. Genet. Vol. 1. Springer-Verlag, Berlin.

TEOH, S. B. AND YONG, H. S. 1983. A spontaneous centric fusion heterozygote in the tropical grasshopper, Valanga nigrocornis (Burmeister). Caryologia, 36, 165-173.

VILARDI, J. C. 1984. Chromosome polymorphism and chiasma frequency in two populations of Staurorhectus longicornis (Orthoptera: Acrididae). Cytologia, 49, 513-528.

wHITE, M. J. D. 1973. Animal Cytology and Evolution. 3rd Ed. Cambridge University Press, London-New York.

wHITE, M. J. D. 1978. Modes of Speciation. W. H. Freeman \& Co., San Francisco. 